\title{
Designing Thermally Pleasant Open Areas: The Influence of Microclimatic Conditions on Comfort and Adaptation in Midwest Brazil
}

\author{
Julia Romero Lucchese ${ }^{1,2}$ \& Wagner Augusto Andreasi ${ }^{1,2}$ \\ ${ }^{1}$ Faculty of Engineering, Architecture and Urban Planning and Geography, Federal University of Mato Grosso \\ do Sul, Campo Grande, Brazil \\ ${ }^{2}$ Laboratory of Analysis and Development of Buildings (LADE), Federal University of Mato Grosso do Sul, \\ Campo Grande, Brazil \\ Correspondence: Julia Lucchese, Universidade Federal de Mato Grosso do Sul, Cidade Universitaria, Caixa \\ Postal 549, 79070-900, Campo Grande-MS, Brazil. Tel: 55-67-3345-7378. E-mail: julialucchese@gmail.com
}

Received: March 4, 2017 Accepted: July 17, $2017 \quad$ Online Published: July 30, 2017

doi:10.5539/jsd.v10n4p11 URL: https://doi.org/10.5539/jsd.v10n4p11

\begin{abstract}
The increasing temperatures in urban areas can negatively affect the health and comfort of its dwellers. Thus, this study assessed thermal comfort conditions in a public square, located in hot-humid Midwest Brazil, based on the relationship between microclimate conditions, thermal sensations and adaptation. Data used were collected through micrometeorological measurements and questionnaire surveys, which were performed simultaneously in field campaigns during hot and cold seasons. The aim was to propose design guidelines for open areas according to local thermal preferences. An updated regionally-calibrated Physiological Equivalent Temperature (PET) assessment scale is also proposed. Neutral temperatures were estimated on a seasonal basis and critical discomfort hours on a monthly basis. The results reaffirm that psychological and behavioral factors influence the individuals' assessment of the outdoor thermal environment and therefore should be considered as design criteria. To improve the microclimate of urban open areas in Campo Grande, shading must be provided primarily by trees and resting areas should be protected from wind exposure. The use of water features for evaporative cooling purposes is not recommended, however, drinking fountains should be available in public squares. Such results can be used by landscape architects and urban planners to deliver thermally comfortable open spaces, encouraging greater use and increased length of stay in these areas.
\end{abstract}

Keywords: field experiment, outdoor thermal comfort, hot-humid climate, Physiological Equivalent Temperature (PET), landscape architecture

\section{Introduction}

Mean annual temperatures in cities are expected to increase by up to $4.9^{\circ} \mathrm{C}$ by the $2080 \mathrm{~s}$ as a consequence of climate change and the urban heat island effect (UCCRN, 2015). Due to dramatic projections as this, climate resilience has become an environmental priority towards sustainable development all over the world. Given the potentially harmful impacts of high temperatures on the comfort of city inhabitants, urban heating mitigation must be made a priority by planning authorities (Ketterer \& Matzarakis, 2014) by means of conscientious design. Environmental conditions in cities can be improved by appropriate arrangement of urban elements, as they determine sun and wind exposure directly impacting the local microclimate (Thorsson et al., 2011).

The increasing temperature of cities is a particularly relevant issue in tropical countries, such as Brazil. Recent Brazilian studies have assessed outdoor thermal comfort conditions with focus on physical attributes of the city, such as: urban geometry (Krüger et al., 2011), Sky View Factor (Minella et al., 2011), ventilation (Silva \& Alvarez, 2015), vegetation (Abreu-Harbich et al., 2015), surface properties and land use (Carfan et al., 2014). Thus, a study more focused on psychological factors can be of significant contribution to better practices of climate-sensitive design in Brazil.

The conventional concept of thermal comfort involves physical and physiological aspects, thus most studies are based on theoretical thermoregulatory models (Nikolopoulou, 2011). But studies conducted in Europe (temperate climate predominantly) (Nikolopoulou et al., 2001; Nikolopoulou \& Steemers, 2003; Thorsson et al., 2004) and 
Taiwan (hot-humid climate) (Lin, 2009; Lin et al., 2013) have demonstrated that psychological and behavioral thermal adaptation play an important role on the individual's perception of the outdoor thermal conditions. Therefore, it is not enough to design open spaces based on the physical environment only (Nikolopoulou \& Steemers, 2003).

From the physiological point-of-view (objective), the relationship between microclimate conditions and human thermal comfort was assessed in this study using Physiological Equivalent Temperature (PET) (Höppe, 1999). PET is a thermal index extensively applied in urban outdoor studies. It is calculated based on four climatic variables (mean radiant temperature, air temperature, air velocity and relative humidity) and two personal variables (clothing insulation and metabolic rate). From the psychological point-of-view (subjective), the relationship between microclimate conditions and human thermal comfort was assessed based on the factors proposed in Nikolopoulou and Steemers (2003). According to the authors, the adaptive opportunity (the degree of which people can adapt to the environment) can be separated into three main categories: physical (reactive and interactive), physiological (or acclimatization) and psychological (naturalness, past experience, perceived control, time of exposure, environmental stimulation and expectations). In this study, such psychological adaptation factors are addressed individually and related to both microclimate conditions and thermal sensations.

The aim of this study is to propose design guidelines for open areas in the city of Campo Grande (Midwest Brazil) based on local psychological and physiological thermal preferences. It was done so by evaluating the relationship between microclimate conditions, thermal sensations and adaptation. Data used were collected through micrometeorological measurements and questionnaire surveys, which were performed in field campaigns during cold and hot seasons. Climate adaptation is a relatively new field thus knowledge is still scarce and fragmented (UNISDR, 2012). Therefore, the proposal of design measures to improve environmental conditions in cities is of urgent importance, as climate change will inevitably increase the susceptibility of urban societies if effective adaptations do not take place soon (UNHABITAT, 2011). The application of bioclimatic concepts in landscape architecture contributes to deliver environments which are thermally suitable according to local preferences, encouraging greater use and increased length of stay in outdoor spaces.

\section{Method}

\subsection{Study Area}

Campo Grande (20 $28^{\prime} 13^{\prime \prime}$ S, 54 $37^{\prime} 25^{\prime \prime}$ W, 600m elevation) is the capital of Mato Grosso do Sul state, located in Midwest Brazil (Figure 1). It is situated between Paraná and Paraguai, the two largest rivers in the region and about $400 \mathrm{~km}$ away from Pantanal, the biggest wetland area in the world (an UNESCO World Heritage Site). The estimated population size of Campo Grande in 2015 was 853.622 inhabitants (IBGE, 2010). The local climate is characterized by extended hot season and it can be described as Temperate hot summer without dry seasons (Cfa), borderline Tropical Savannah zone (Aw), under Köppen-Geiger classification (Peel et al., 2007). The mean air temperature in Campo Grande in Summer is $25.2{ }^{\circ} \mathrm{C}, 25.1^{\circ} \mathrm{C}$ in Spring and $22.3{ }^{\circ} \mathrm{C}$ in Winter (2008-2015) (CEMTEC, 2016).

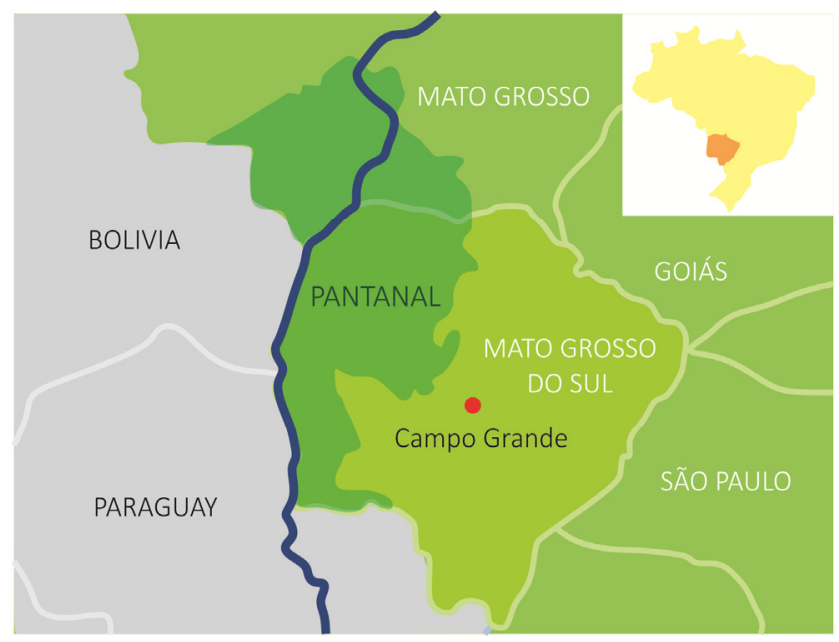

Figure 1. Location of Campo Grande city in Brazil

The focus of this study is Ary Coelho Square (Figure 2), which was selected as study area due to its high density of usage, being inserted in a predominantly commercial district located right in the city center. It also has 
relevant cultural and historical importance as it was the first public open space in the city, inaugurated in 1909. The square went through revitalization in 2011, as the municipality aims to preserve local architectural heritage and improve the environmental quality of the city center. Its surroundings consist mainly of one to two-storey commercial buildings and streets with high levels of traffic (Figure 3). Ary Coelho comprises a total area of $14.400 \mathrm{~m}^{2}$ and approximately $30 \%$ of its surface is vegetation Shading density varies along the square, being provided mainly by trees. Mean Sky View Factor obtained is 0.37 (partially shaded), which was calculated uploading fish-eye photos of nine selected locations into the software RayMan v. 1.2 (Matzarakis, 2007).

\subsection{Data Collection}

Micrometeorological measurements were taken at the same time that questionnaire surveys were conducted. Data were collected under clear-sky conditions in winter (July 18 and 22, 2015), spring (November 10 and 12, 2015) and summer (February 20, 2016), comprising a total of five days of measurements and 524 valid thermal comfort questionnaires. Considering the population size of Campo Grande, a minimum of 400 questionnaires (5\% sampling error) can be considered as an acceptable sample size, according to the equation proposed in Barbetta (2006). Only permanent visitors were included in the research, passers-by were excluded. This is justified by the fact that thermal discomfort does not result in serious consequences when exposure time is short. On the other hand, prolonged exposure can be harmful to human health (Nikolopoulou et al., 2001; Thorsson et al., 2004).

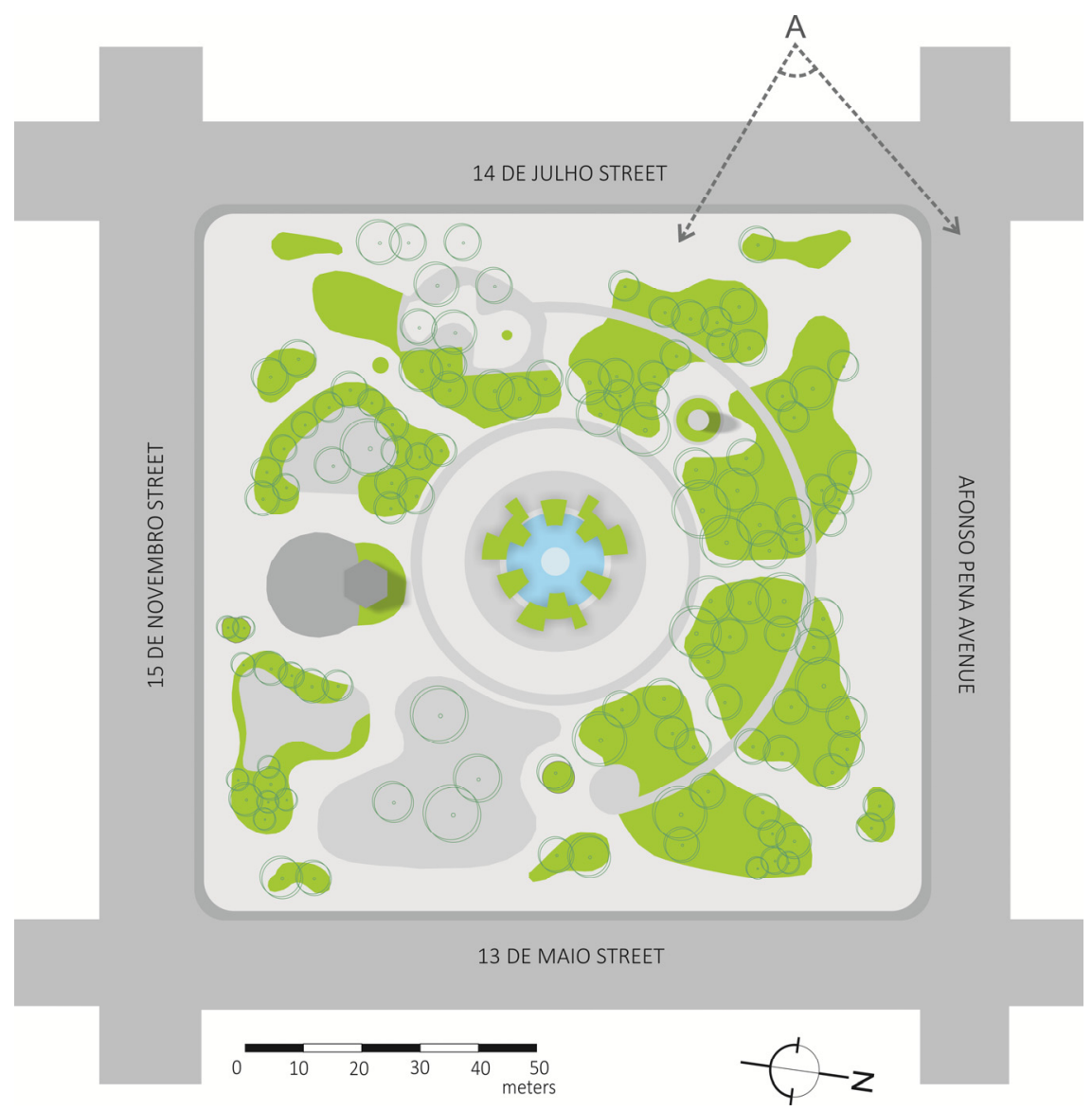

Figure 2. Investigated site, Ary Coelho Square. 


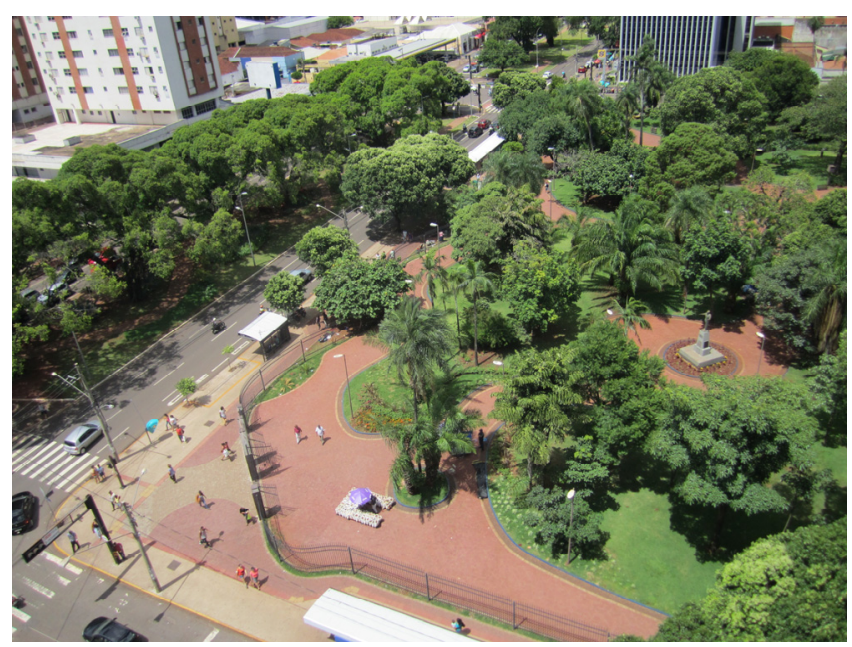

Figure 3. Bird's-Eye View A.

\subsubsection{Micrometeorological Monitoring}

A calibrated microclimatic station BABUC-A was used in the monitoring, which was mounted on an adjustable tripod at $110 \mathrm{~cm}$ and placed on the southwest portion of the square (for practical and safety reasons). Climate variables monitored included: air temperature $\left({ }^{\circ} \mathrm{C}\right)$, air humidity $(\%)$, wind speed $(\mathrm{m} / \mathrm{s})$ and globe temperature $\left({ }^{\circ} \mathrm{C}\right)$. The collected data were stored into a data logger, processed through InfoGAP software and then averaged over 1 minute. Measurements were taken from 0900 until 1200 in winter and spring, and from 1400 until 1700 in summer, so that a wide range of climate conditions would be covered. Mean radiant temperature was estimated using RayMan v. 1.2 (Matzarakis 2007) model. Monitoring was performed following ISO 7726 (1998). Even though the Standard provides guidance for measuring physical variables in indoor environments, it has successfully been applied in outdoor thermal comfort studies as well (Silva \& Alvarez, 2015; Ruiz \& Correa, 2015).

\subsubsection{Questionnaire Surveys}

The thermal comfort questionnaire was applied randomly within the perimeter of the square. It was essentially divided in three parts: Personal Variables (1), Thermal Adaptation (2), and Thermal Sensation Vote (TSV) (3). Personal Variables (1) refered to the respondents' personal information, such as age, height, weight, gender, clothing insulation and metabolic rate. Metabolic rate is related to the degree of activity of the body. It was estimated in accordance with ISO 7730 (2005) and represented in the unit 'met'. Clothing insulation was estimated according to the same Standard and its value represented in the unit 'clo'. Such information was necessary to calculate the thermal index of each individual. In the Thermal Adaptation (2) section, people were asked about their behavioral adjustments when feeling hot (for example: seek shade of tree, drink cold beverage) and motivation to visit the square (necessary to evaluate if the individual remained in the square by choice or against their will). To acquire the Thermal Sensation Vote (TSV) (3), respondents were asked how they were feeling at that moment. The answer options were organized in a seven-point scale, ranging from "very cold" (-3), "cold" (-2), "slightly cold" (-1), to "neutral" (0), "slightly hot" $(+1)$, "hot" $(+2)$ and "very hot" $(+3)$. The scale was elaborated following the recommendations of Standard ISO 10551 (1995), which provides guidelines to assess the thermal environment through judgment scales.

\subsection{Thermal Index}

Thermal indices are used to quantify and assess predicted comfort sensation votes. The thermal index used in this study was the Physiological Equivalent Temperature (PET) (Mayer \& Höppe, 1987), which is one of the most used outdoor thermal comfort indices around the world. PET's wide application enables the comparison of results of this study with others in different geographic and climatic contexts. The index was calculated based on the following climatic variables: air temperature $\left({ }^{\circ} \mathrm{C}\right)$, air velocity $(\mathrm{m} / \mathrm{s})$ and relative humidity $(\%)$; all measured at $110 \mathrm{~cm}$ above surface. Such variables, collected during field campaigns, were then used as input data in RayMan v. 1.2 (Matzarakis 2007), which is a widely used public domain microclimatic model. The software's popularity can be partly explained by its ease of use and by the fact that it can estimate mean radiant temperature, a difficult variable to calculate (Gómez et al., 2013). Indeed, mean radiant temperature was estimated using the model. 
PET result is expressed quantitatively in degrees Celsius $\left({ }^{\circ} \mathrm{C}\right)$ and the correspondent thermal sensation can be estimated based on a nine-degree interpretative range. Ideally, this scale must be regionally adjusted based on subjective votes obtained in field campaigns. The calibration of PET's assessment ranges for the physiological reality of Campo Grande's inhabitants was proposed in Lucchese et al. (2016) and it was adopted in this study with a few adjustments (Table 1).

Table 1. Calibrated PET assessment scale for Campo Grande/Brazil

\begin{tabular}{|c|c|c|c|}
\hline $\begin{array}{c}\text { TSV } \\
\text { equivalent }\end{array}$ & Sensation & $\begin{array}{l}\text { PET-Central Europe }\left({ }^{\circ} \mathrm{C}\right) \\
\text { (conventionally used scale) }\end{array}$ & $\begin{array}{c}\text { PET-Campo Grande }\left({ }^{\circ} \mathrm{C} \text { ) }\right. \\
\text { (regionally-calibrated scale) }\end{array}$ \\
\hline-3 & Very cold & PET $\leq 4$ & $\mathrm{PET} \leq 11$ \\
\hline \multirow[t]{2}{*}{-2} & Cold & $4<\mathrm{PET} \leq 8$ & $11<\mathrm{PET} \leq 15$ \\
\hline & Cool & $8<\mathrm{PET} \leq 13$ & - \\
\hline-1 & Slightly cool & $13<\mathrm{PET} \leq 18$ & $15<\mathrm{PET} \leq 21$ \\
\hline 0 & Neutral & $18<\mathrm{PET} \leq 23$ & $21<\mathrm{PET} \leq 27$ \\
\hline \multirow[t]{2}{*}{+1} & Slightly warm & $23<\mathrm{PET} \leq 29$ & $27<\mathrm{PET} \leq 33$ \\
\hline & Warm & $29<\mathrm{PET} \leq 35$ & - \\
\hline+2 & Hot & $35<\mathrm{PET} \leq 41$ & $33<\mathrm{PET} \leq 39$ \\
\hline+3 & Very hot & PET $>41$ & PET > 39 \\
\hline \multicolumn{2}{|c|}{ References } & Matzarakis and Mayer (1996) & Lucchese et al. (2016) \\
\hline
\end{tabular}

\section{Results and Discussion}

\subsection{Relationship between Microclimatic Variables and Thermal Sensation Votes}

\subsubsection{Mean Radiant Temperature and Air Temperature}

During the five days of field campaigns, the minimum air temperature monitored in the square occurred in winter $\left(15.3{ }^{\circ} \mathrm{C}\right)$ and maximum in spring $\left(32.3{ }^{\circ} \mathrm{C}\right)$. As for mean radiant temperature, minimum occurred in winter $\left(17.3{ }^{\circ} \mathrm{C}\right)$ and maximum in summer $\left(34.4^{\circ} \mathrm{C}\right)$. Many studies have emphasized the importance of mean radiant temperature in the assessment of outdoor thermal comfort conditions (Thorsson et al., 2004; Matzarakis et al., 2007; Krüger et al., 2011). In situations of sun exposure, mean radiant temperature can be regarded as a parameter that more accurately assess outdoor thermal comfort conditions than air temperature, which is the main variable conventionally adopted (Minella et al., 2011). Pearson correlation coefficients resulting from the association between the climate variables and thermal sensation votes were compared. Indeed, the results indicate a slightly greater association between TSV and mean radiant temperature $\left(\mathrm{r}^{2}=0.55\right)$ than TSV and air temperature $\left(r^{2}=0.54\right)$. Since sensation votes are a subjective parameter, correlations were interpreted based on Cohen (1988). The author defined a value of 0.1 as of small, 0.3 as of medium and 0.5 or greater as of large association between variables (in the context of behavioral science).

\subsubsection{Relative Humidity}

During the experiment, the minimum relative humidity monitored in the square occurred in winter $(42.6 \%)$ and maximum also in winter (68.2\%). To assess if the variable was perceived by people positively or negatively, thermal sensation votes were distributed in PET intervals, in groups of different relative humidity ranges (Figure 4). The results indicate that relatively high values of relative humidity $(60-70 \%)$ did not cause desirable effect on the visitors' thermal conditions when PET values were below $20{ }^{\circ} \mathrm{C}$ and above $30{ }^{\circ} \mathrm{C}$ PET. Comparing the amplitude of each relative humidity range, $60-70 \%$ had votes most distant from the central line of comfort $(\mathrm{TSV}=0)$. That is, the longer the arrow, more uncomfortable people were within that range. $40-50 \%$ range was stated as the most comfortable condition for the square visitors. 


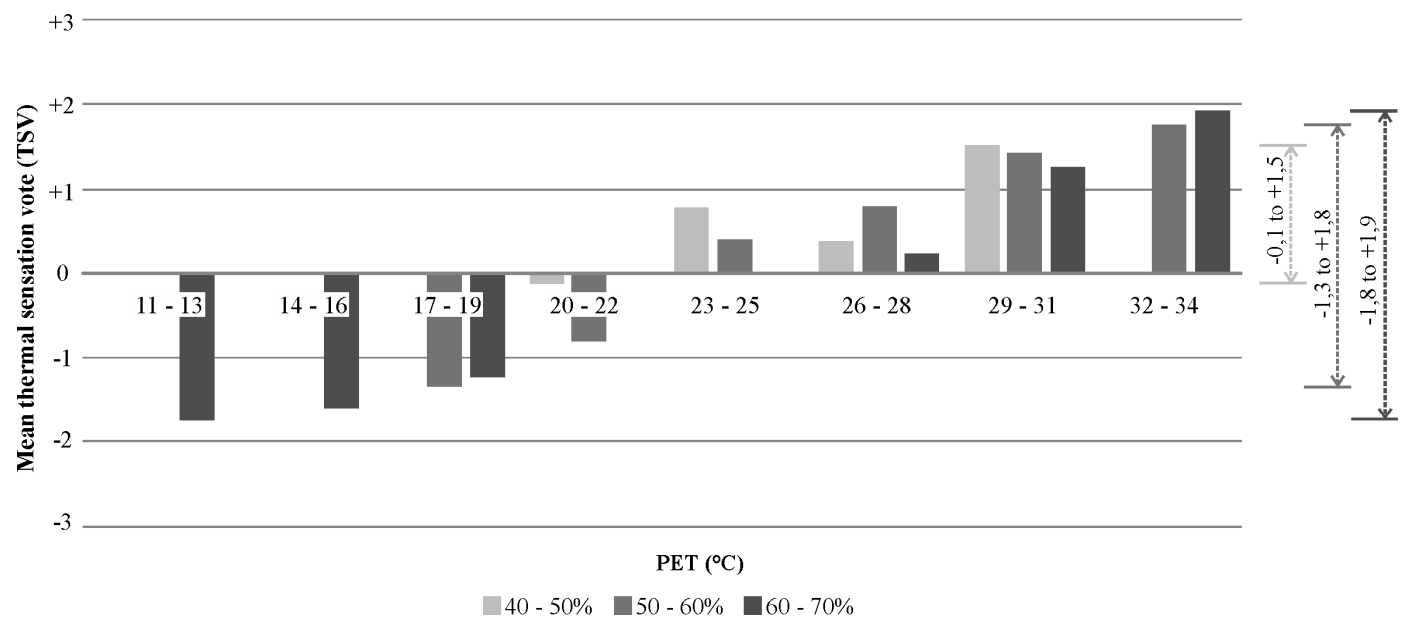

Figure 4. Amplitude of sensation votes as a function of PET ranges regarding relative humidity.

\subsubsection{Wind Speed}

During the field campaigns, the minimum wind speed monitored in the square occurred in spring $(0.1 \mathrm{~m} / \mathrm{s})$ and maximum also in spring $(5.5 \mathrm{~m} / \mathrm{s})$, all measured at $110 \mathrm{~cm}$. Ventilation accelerates the heat exchange between the human body and the environment, which makes it a particularly important cooling strategy in tropical humid climate zones (Silva \& Alvarez, 2015). During hot seasons, high air velocities have a desirable effect but during cold seasons, high wind speeds can result in thermal discomfort. The amplitude of the sensation votes was analyzed (Figure 5). The results indicate that, within the range $11-16^{\circ} \mathrm{C}$ PET, wind caused undesirable cooling to most people. Air velocity of $1 \mathrm{~m} / \mathrm{s}$ was desirable in the range $17-22^{\circ} \mathrm{C}$ PET but it was insufficient to provide thermal comfort conditions at such speed after this interval. Within the range $23-25{ }^{\circ} \mathrm{C}$ PET, winds of 3 to $4 \mathrm{~m} / \mathrm{s}$ provided thermal comfort to most respondents. From $28^{\circ} \mathrm{C}$ PET on, wind ceased to provide comfortable cooling (even at high speeds) and started to cause undesirable heating by convection.

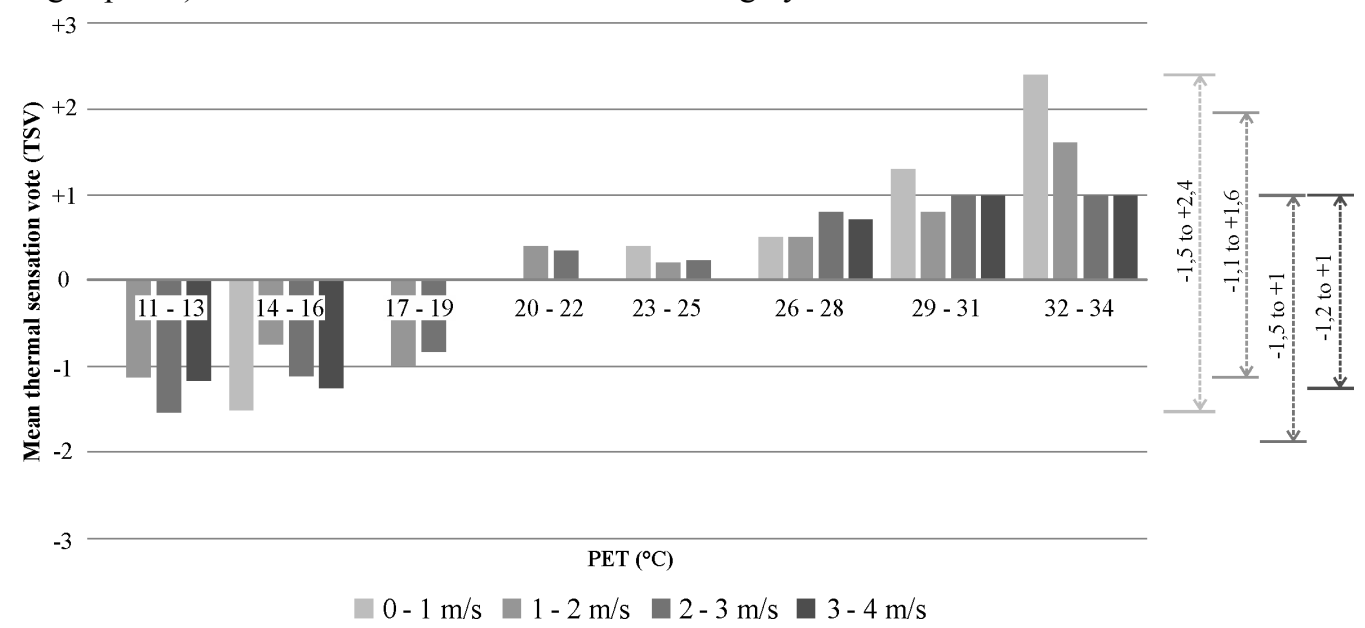

Figure 5. Amplitude of sensation votes as a function of PET ranges regarding air velocity.

\subsection{Relationship between Thermal Adaptation and Thermal Sensation Votes}

\subsubsection{Behavioral Adaptation}

Changes in the environment, that result in thermal discomfort, induce people to take behavioral actions seeking to restore their comfort conditions (Nicol, 2004). With this in mind, interviewees were asked what their favorite adaptation strategies were when experiencing heat discomfort. Only heat discomfort was investigated because the local climate is characterized by an extended hot season. Most people stated that they move to an area shaded by trees (47\%). Only $3 \%$ stated that they would rather move to an area shaded by an artificial structure. This could be explained by the psychological parameter "naturalness". According to Nikolopoulou and Steemers (2003), naturalness is based on the assumption that people are more tolerant to situations of discomfort when 
natural elements, rather than artificial ones, predominate in the landscape. Another relevant strategy was drinking cold beverages $(41 \%)$, which can be explained by cultural habits. The consumption of tereré is very popular locally, which is a traditional beverage made of yerba mate (crushed dried leaves) infusion with cold water. As verified by Lin et al. (2013), there are limitations to certain strategies, such as adjusting clothes, in hot-humid regions. According to the authors, people are unable to reduce clothing during hot seasons as they normally already dress minimally. This could explain why only $5 \%$ of the interviewees chose this option.

\subsubsection{Perceived Control}

One of the reasons why thermal adaptation outdoors is particularly interesting is due to the fact that people have little control over the source of discomfort in open spaces (Ruiz \& Correa, 2015). Perceived control can be investigated by considering whether people remain in a given place by choice or against their will. Lin (2009) and Lin et al. (2013) demonstrated that the level of autonomy of people in Taiwanese public squares significantly influences their perception of the thermal environment. According to the authors, people with higher levels of autonomy are more satisfied with their thermal conditions and thus better tolerate discomfort. In this study, the results reveal that, within the same PET intervals, people with low and high autonomy stated different mean thermal sensation votes (Figure 6). This difference suggests that autonomous people have a larger thermal tolerance than non-autonomous people.

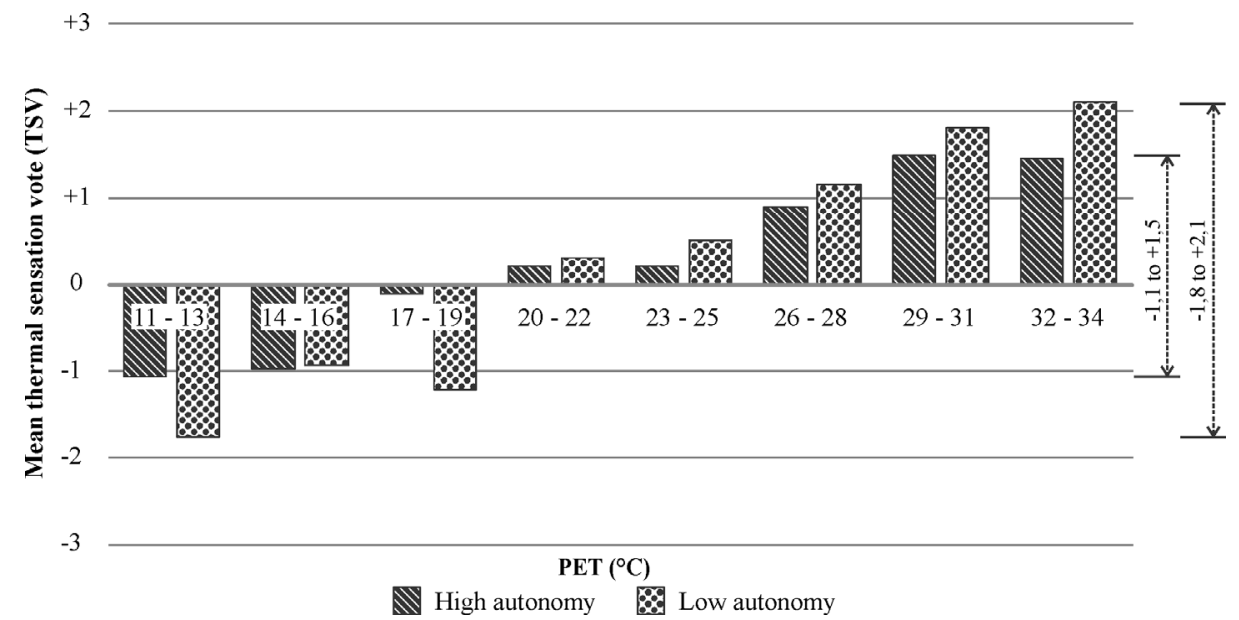

Figure 6. Amplitude of sensation votes as a function of PET ranges regarding autonomy levels.

\subsubsection{Past Experience and Expectations}

Past experience (physical, physiological and psychological) influences human thermal comfort, since expectation leads people to compare current with previous climate conditions. Thus, past experience in a particular place and time changes the way the thermal environment is perceived by people (Lin, 2009). This is particularly evident in the seasonal variation of neutral temperatures (that is, temperature where people feel neither warm nor cold) (Nikolopoulou, 2011). Seasonal variation of neutral temperature is an example of thermal adaptation linked to psychological factors because, under the physiological perspective, there should be no difference as seasons change.

Thermal sensation votes were analyzed based on the hypothesis that the temperature people feel comfortable with is that they have experienced before. Mean TSVs were grouped into $2{ }^{\circ} \mathrm{C}$ PET intervals and determined on a seasonal basis. A regression line was plotted and the equations for winter (1), spring (2) and summer (3) were estimated, which determine neutral PET temperatures (when mean TSV=0). The value obtained for winter was $23.1^{\circ} \mathrm{C}$ PET, spring $23.3{ }^{\circ} \mathrm{C}$ PET and summer $24.4^{\circ} \mathrm{C}$ PET.

$$
\begin{aligned}
& \text { Winter: } T S V_{\text {mean }}=0.1629 * \text { PET-3.7686 } \\
& \text { Spring: } T S V_{\text {mean }}=0.1971 * \text { PET-4.5895 } \\
& \text { Summer: } T S V_{\text {mean }}=0.1905 * \text { PET-4.6561 }
\end{aligned}
$$

Similar studies have found different neutral temperature values in different seasons (Table 4). Lin (2009) demonstrated that experience reminds people that the air temperature in summer is higher than in winter, hence people's tolerance for high temperatures in summer is high, and its neutral temperature is higher than in winter. 
The same study suggests that, as the annual variation of temperature increases, the difference between the neutral temperatures also increases. This indicates that the annual temperature variance of a given region influences the adaptation of local residents. These are in accordance with results found in this study.

Table 4. Neutral temperatures in different geographic and climatic contexts

\begin{tabular}{|c|c|c|c|c|c|}
\hline Climate and location & $\begin{array}{l}\text { Hot season } \\
\text { (summer) }\end{array}$ & $\begin{array}{l}\text { Cold season } \\
\text { (winter) }\end{array}$ & Difference & $\begin{array}{l}\text { Annual variation } \\
\text { of air temperature }\end{array}$ & Reference \\
\hline $\begin{array}{c}\text { Temperate } \\
\text { (Cambridge/ UK) }\end{array}$ & $28{ }^{\circ} \mathrm{C}$ & $8{ }^{\circ} \mathrm{C}$ & $20^{\circ} \mathrm{C}$ & $\begin{array}{c}28^{\circ} \mathrm{C} \\
\left(1 \text { to } 29^{\circ} \mathrm{C}\right)\end{array}$ & $\begin{array}{l}\text { Nikolopoulou } \\
\text { et al. (2001) }\end{array}$ \\
\hline $\begin{array}{l}\text { Humid subtropical } \\
\text { (Sydney/ Australia) }\end{array}$ & $33^{\circ} \mathrm{C}$ & $23{ }^{\circ} \mathrm{C}$ & $10^{\circ} \mathrm{C}$ & $31{ }^{\circ} \mathrm{C}$ & $\begin{array}{l}\text { Spagnolo and } \\
\text { De Dear } \\
(2003)\end{array}$ \\
\hline $\begin{array}{c}\text { Hot-humid } \\
\text { (Taichung/ Taiwan) }\end{array}$ & $25.6{ }^{\circ} \mathrm{C}$ PET & $\begin{array}{c}23.7^{\circ} \mathrm{C} \\
\text { PET }\end{array}$ & $1.9^{\circ} \mathrm{C}$ PET & $\begin{array}{c}17^{\circ} \mathrm{C} \\
\left(18 \text { to } 35^{\circ} \mathrm{C}\right)\end{array}$ & Lin (2009) \\
\hline $\begin{array}{c}\text { Hot-humid } \\
\text { (Campo Grande/ Brazil) }\end{array}$ & $24.4^{\circ} \mathrm{C}$ PET & $\begin{array}{c}23.1^{\circ} \mathrm{C} \\
\text { PET }\end{array}$ & $1.3{ }^{\circ} \mathrm{C}$ PET & $\begin{array}{c}14{ }^{\circ} \mathrm{C} \\
\left(16 \text { to } 30^{\circ} \mathrm{C}\right)\end{array}$ & This study \\
\hline
\end{tabular}

\subsection{Estimating Local Discomfort Hours}

To estimate the hours of critical discomfort locally, mean PET values were calculated hourly for winter, spring and summer months. Climatic data used were obtained from Campo Grande's EnergyPlus weather file (EPW) format, downloaded from the U.S. Department of Energy website (historical series 1973-1991). Clothing insulation was set as constant based on the mean values obtained in the field campaigns: for winter 0.6 clo, spring 0.5 clo and summer 0.5 clo. Default value for metabolic rate was used $(80 \mathrm{~W})$.

A thermal condition can be considered "acceptable" when TSVs are "slightly hot" (+1), "comfortable" (0) or "slightly cold" (-1) (ISO 7730, 2005). Thus, these votes were grouped in a central "no thermal stress" zone. Applying the regionally-adjusted PET interpretative scale (Table 2), discomfort hours were estimated for winter (Figure 7), spring (Figure 8) and summer (Figure 9) months.

WINTER

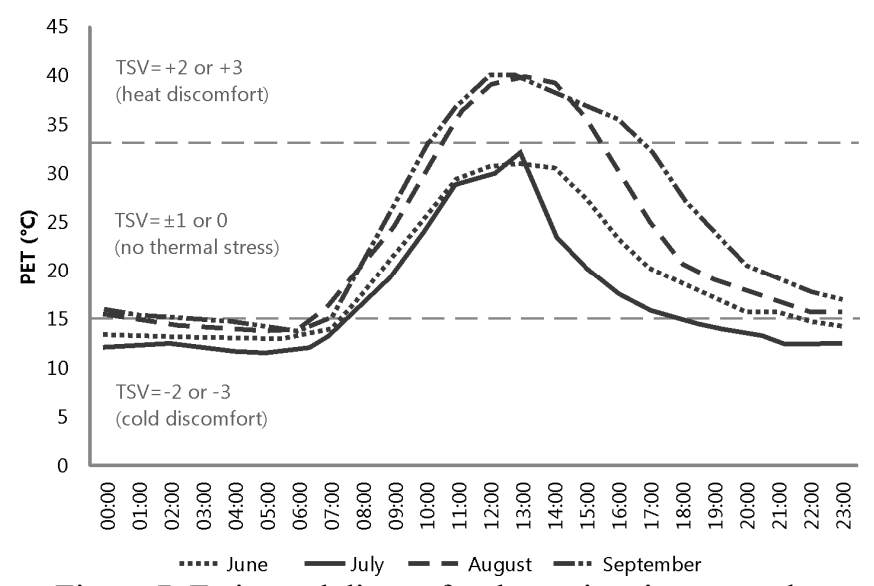

Figure 7. Estimated discomfort hours in winter months. 


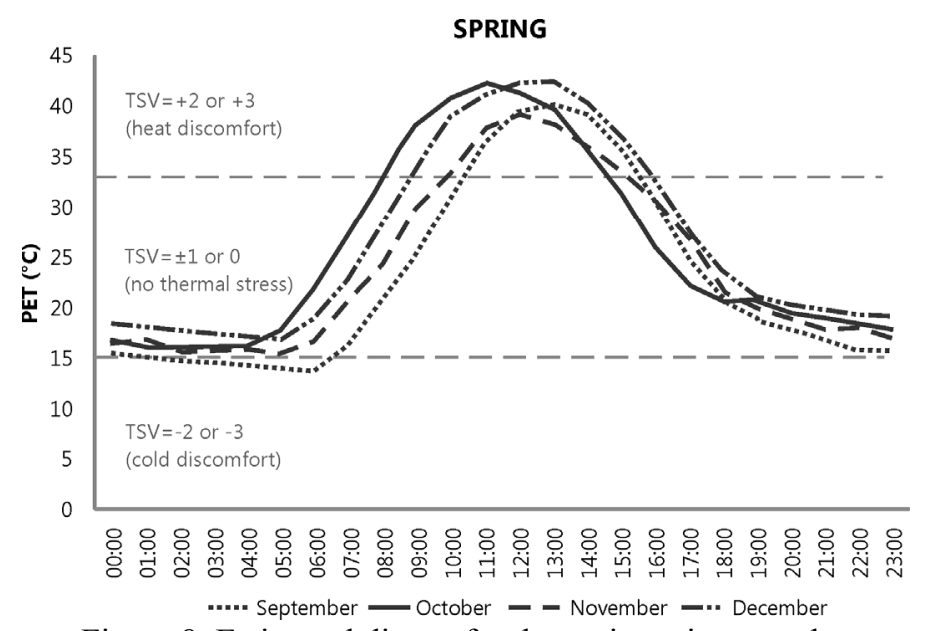

Figure 8. Estimated discomfort hours in spring months.

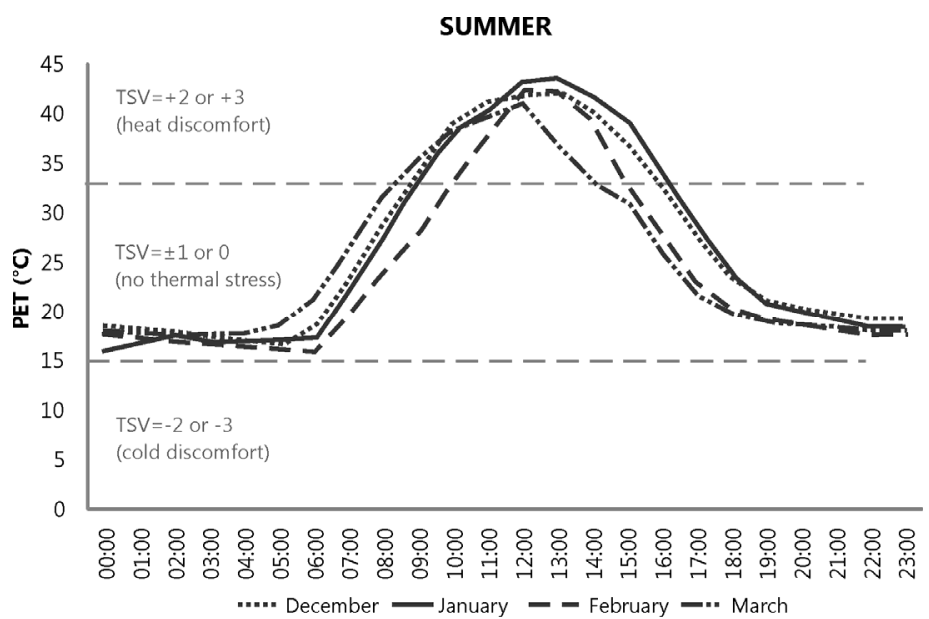

Figure 9. Estimated discomfort hours in summer months.

Winter provides more discomfort hours ( $48 \%$ average) than spring (32\% average) and summer ( $28 \%$ average). However, (cold) discomfort hours in winter prevail between 0000 and 0700 , when public squares do not have a significant number of visitors. During spring and summer, (heat) discomfort hours prevail when public squares have high flow of visitors (0730 to 1700). The results reinforce the importance of providing improved microclimate conditions in urban open areas, aiming to encourage greater use of open spaces and increased length of stay of visitors.

\section{Conclusions}

The results reaffirm that psychological and behavioral factors influence the individuals' assessment of the outdoor thermal environment and therefore should be considered as design criteria. To improve the microclimate of urban open areas in Campo Grande, shading must be provided primarily by trees, given the preference of respondents for naturally-shaded spaces. Furthermore, trees decrease both air temperature and mean radiant temperature and such variables are strongly related to outdoor thermal sensations. Resting places should be protected from direct wind exposure using removable barriers (used according to necessity). The use of water features for evaporative cooling purposes is not recommended, since lower relative humidity values provide better comfort conditions. However, drinking fountains should be available in public squares of Campo Grande. It is of great importance that different microclimates are provided in urban open areas, so that visitors can have the opportunity of choice (perceived control) throughout the day and seasons according to their personal needs. Nevertheless, such microclimates should be mostly designed to provide cooler conditions, since visitors are more exposed to heat discomfort.

\section{References}

Abreu-Harbich, L. V., Labaki, L. C., \& Matzarakis, A. (2015). Effect of tree planting design and tree species on 
human thermal comfort in the tropics. Landscape and Urban Planning 138, 99-109.

Barbetta, P. A. (2006). Estatística Aplicada às Ciência Sociais (5th ed.). Florianópolis, SC: UFSC.

Carfan, A. C., Galvany, E., \& Nery, J. T. (2014). Land Use and Thermal Comfort in the County of Ourinhos, SP. Current Urban Studies, 2, 140-151. https://doi.org/10.4236/cus.2014.22014

CEMTEC. (n.d.). Centro de Monitoramento de Tempo, do Clima, e dos Recursos Hídricos de Mato Grosso do Sul. Retrieved April 2, 2016, from www.cemtec.ms.gov.br

Cohen, J. (1988). Statistical power analysis for the behavioral sciences. Hillsdale, NJ: Erlbaum.

Gómez, F., Cueva, A.P., Valcuende, M., \& Matzarakis, A. (2013). Research on ecological design to enhance comfort in open spaces of a city (Valencia, Spain). Utility of the physiological equivalent temperature (PET). Ecological Engineering, 57, 27-39. https://doi.org/10.1016/j.ecoleng.2013.04.034

Höppe, P. (1999) The Physiological Equivalent Temperature - A universal index for the biometeorological assessment of the thermal environment. International Journal of Biometeorology, 43, 71-75. https://doi.org/10.1007/s004840050118

IBGE. (n.d.). Instituto Brasileiro de Geografia e Estatística. Retrieved October 29, 2016, from www.ibge.org.br/english

International Organization for Standardization. (1995). ISO 10551: Ergonomics of the thermal environment Assessment of the influence of the thermal environment using subjective judgment scales. Geneva.

International Organization for Standardization. (1998). ISO 7726: Ergonomics of thermal environment Instruments for measuring physical quantities. Geneva.

International Organization for Standardization. (2005). ISO 7730: Ergonomics of thermal comfort using calculation of PMV and PPD indices and local thermal comfort criteria. Geneva.

Ketterer, C., \& Matzarakis, A. (2014). Human-biometeorological assessment of heat stress reduction by replanning measures in Stuttgart, Germany. Landscape and Urban Planning, 122, 78-88. https://doi.org/10.1016/j.landurbplan.2013.11.003

Krüger, E. L., Minella, F. C. O., \& Rasia, F. B. C. (2011). Impact of urban geometry on outdoor thermal comfort and air quality from field measurements in Curitiba, Brazil. Building and Environment, 46, 621-634. https://doi.org/10.1016/j.buildenv.2010.09.006

Lin, T.-P. (2009). Thermal perception, adaptation and attendance in a public square in hot and humid regions. Building and Environment, 44(10), 2017-2026. https://doi.org/10.1016/j.buildenv.2009.02.004

Lin, T.-P., Tsai, K.-T., Liao, C.-C., \& Huang, Y.-C. (2013). Effects of thermal comfort and adaptation on park attendance regarding different shading levels and activity types. Building and Environment, 59, 599-611. https://doi.org/10.1016/j.buildenv.2012.10.005

Lucchese, J. R., Mikuri, L. P., De Freitas, N. V. S., \& Andreasi, W. A. (2016). Application of selected indices on outdoor thermal comfort assessment in Midwest Brazil. International Journal of Energy and Environment, 7(4), 291-302.

Matzarakis, A., \& Mayer, H. (1996). Another kind of environmental stress: thermal stress. WHO Collaborating Centre for Air Quality Management and Air Pollution Control. Newsletters.

Matzarakis, A., Rutz, F., \& Mayer, H. (2007). Modeling radiation fluxes in simple and complex environments Application of the RayMan model. International Journal of Biometeorology, 51, 323-334. https://doi.org/10.1007/s00484-006-0061-8

Mayer, H., \& Höppe, P. (1987). Thermal comfort of man in different urban environments. Theoretical and Applied Climatology, 38, 43-49. https://doi.org/10.1007/BF00866252

Minella, F. C. O., Rossi, F. A., \& Krüger, E. L. (2011). Análise do efeito diurno do fator de visão do céu no microclima e nos níveis de conforto térmico em ruas de pedestres em Curitiba. Ambiente Construído, 11, 123-143. https://doi.org/10.1590/S1678-86212011000100009

Nicol, F. (2004). Adaptive thermal comfort standards in the hot-humid tropics. Energy and Buildings, 36, 628-637. https://doi.org/10.1016/j.enbuild.2004.01.016

Nikolopoulou, M. (2011). Outdoor thermal comfort. Frontiers in Bioscience, 3, 1552-1568. https://doi.org/10.2741/s245 
Nikolopoulou, M., \& Steemers, K. (2003). Thermal comfort and psychological adaptation as a guide for designing urban spaces. Energy and Buildings, 35, 95-101. https://doi.org/10.1016/S0378-7788(02)00084-1

Nikolopoulou, M., Baker, N., \& Steemers, K. (2001). Thermal comfort in outdoor urban spaces: understanding the human parameter. Solar Energy, 70, 227-235. https://doi.org/10.1016/S0038-092X(00)00093-1

Peel, M. C., Finlayson, B. L., \& McMahon, T. A. (2007). Updated world map of the Köppen-Geiger climate classification. Hydrology and Earth System Sciences, 11, 1633-1644. https://doi.org/10.5194/hess-11-1633-2007

Ruiz, M. A., \& Correa, E. N. (2015). Adaptive model for outdoor thermal comfort assessment in an Oasis city of arid climate. Building and Environment, 85, 40-51. https://doi.org/10.1016/j.buildenv.2014.11.018

Silva, F. T., \& Alvarez, C. E. (2015). An integrated approach for ventilation's assessment on outdoor thermal comfort. Building and Environment, 87, 59-71. https://doi.org/10.1016/j.buildenv.2015.01.018

Spagnolo, J., \& De Dear, R. (2003). A field study of thermal comfort in outdoor and semi-outdoor environments in subtropical Sydney Australia. Building and Environment, 38, 721-738. https://doi.org/10.1016/S0360-1323(02)00209-3

Thorsson, S., Lindberg, F., Björklund, J., Holmer, B., \& Rayner, D. (2011). Potential changes in outdoor thermal comfort conditions in Gothenburg, Sweden due to climate change: The influence of urban geometry. International Journal of Climatology, 31, 324-335. https://doi.org/10.1002/joc.2231

Thorsson, S., Lindqvist, M., \& Lindqvist, S. (2004). Thermal Bioclimatic Conditions and Patterns of Behaviour in an Urban Park in Göteborg, Sweden. International Journal of Biometeorology, 48, 149-156. https://doi.org/10.1007/s00484-003-0189-8

UCCRN. Urban Climate Change Research Network. (2015). ARC3.2 Summary for City Leaders - Climate Change and Cities: Second Assessment Report. Center for Climate Systems Research, Earth Institute. Columbia University.

UNHABITAT. United Nations Human Settlements Programme. (2011). Cities and Climate Change: Global Report on Human Settlements. Washington, DC: Earthscan.

UNISDR. United Nations International Strategy for Disaster Reduction. (2012). How to make cities more resilient: A handbook for local government leaders. Geneva.

\section{Copyrights}

Copyright for this article is retained by the author(s), with first publication rights granted to the journal.

This is an open-access article distributed under the terms and conditions of the Creative Commons Attribution license (http://creativecommons.org/licenses/by/4.0/). 